\title{
Iron Gates Natural Park - Administration and Management
}

\author{
Sînziana PAULIUC, Marian PROOROCU*, Sonia BODAN, Mădălina MICLĂUŞ \\ Department of Plant and Environmental protection. University of Agriculture Sciences and Veterinary \\ Medicine, Cluj Napoca, Romania \\ *corresponding author, e-mail: mproorocu @yahoo.com
}

Bulletin UASVM series Agriculture 73(2)/2016

Print ISSN 1843-5246; Electronic ISSN 1843-5386

DOI 10.15835/buasvmcn-agr: 12444

\begin{abstract}
This paper analyzes the management and administration of one of the largest, beautiful and complex natural parks from Romania, the Iron Gates Natural Park. The management plan is a frame of integration of the biodiversity conservation problems and protection of the natural and cultural environment that also supports socio-economic development of Iron Gates Natural Park. It is also an instrument of dialog between the institutions which coordinate this area. The management plan is a document approved by H.G 1048/2013 and it resulted after consulting the interested factors of the area (city halls, local and central authorities, civil society). The administration of Iron Gates Natural Park has a new structure, founded in 2003 and is working as a subunit of Forest-National Administration (Romsilva), which assures the necessary personal and equipment for administrating the area. The area has the status of: Natural Park, Natura 2000 and Ramsar site. The forest represents $65 \%$ of the total area, 98\% being a state property. Analysing Iron Gates Natural Park documents (Iron Gates Natural Park management plan, scientific council and park administration documents, visits and observations within park), we can conclude that the park has a good administration leaded by the scientific councils, who also achieved many successful European projects.
\end{abstract}

Keywords: administration, conservation, management plan, natural park, nature.

Introduction. Iron Gates Natural Park is essential in the conservation of the natural and cultural capital because includes the most representative and significant areas of biodiversity, but also natural and cultural values. This area represents an example of harmonious cohabitation of people and nature (Proorocu, 2008; Samad, 2008).

Aims. This paper analyzes the management and administration of one of the largest, beautiful and complex natural parks from Romania, the Iron Gates Natural Park.

Materials and Methods. Iron Gates Natural Park management plan, scientific council and park administration documents were analysed; visits and observations within park
Results and Discussion. Iron Gates Natural Park has a management plan approved by H.G 1043/2013. It has the status of: Natural Park, Natura 2000 and Ramsar site. The forest represents $65 \%$ of the total area, $98 \%$ being a state property. Dacian and Mediterranean vegetation interact, forming a complex of plant groups that constitute the sub-Mediterranean vegetation type. The administrative expenses are $70 \%$ higher than the incomes, which are supported by the Forestry Department of Mehedinti. The incomes that we appreciate as substantial, 306.958 lei in the first 3 quarters of 2015 are cashed from tourism, approvals and other services (Fig. 1, Tab. 1). Regarding the research and conservation activities, these were carried out in numerous projects with external funding. 


\section{Administration expenses for the Iron Gates Natural Park}

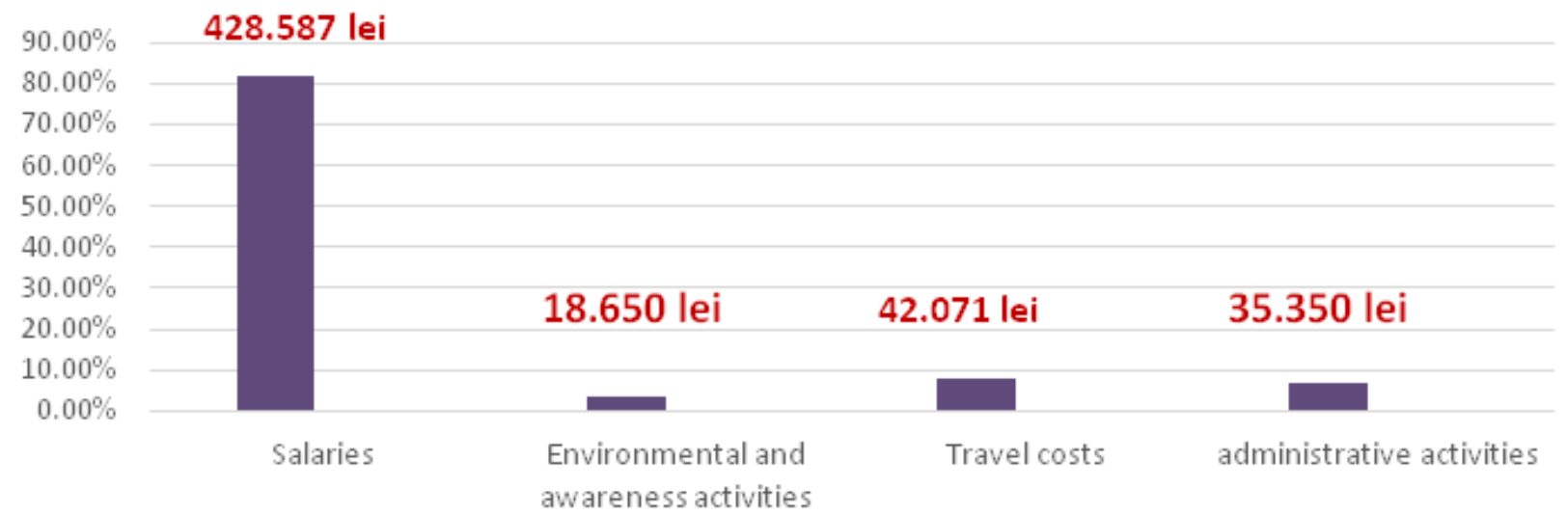

Administration expenses for the Iron Gates Natural Park

Fig. 1. Structure costs for administering the Iron Gates Natural Park

( http://www.pnportiledefier.ro/)

Tab. 1. Financial income(http://www.pnportiledefier.ro/)

\begin{tabular}{lccc}
\hline No. & Issue & Values & $\%$ \\
\hline 1 & Tourist service & $215.298,00$ & 70 \\
\hline 2 & Approval documentation & $55.502,00$ & 18 \\
\hline 3 & Other incomes & $36.157,00$ & 12 \\
\hline & Total & 306.957 & 100 \\
\hline
\end{tabular}

Conclusion. Analysing Iron Gates Natural Park documents, we can conclude that the park has a good administration leaded by the scientific councils, who also achieved many successful European projects.

\section{REFERENCES}

1. Proorocu M 2008, Protected Natural Areas, Edit. Academic Press, Cluj-Napoca

2. Samad SJ 2008, Management of tourism in protected natural areas, Edit. Risoprint, Cluj-Napoca

3. ***, Iron Gates Natural Park Management Plan. On line at: http://ec.europa.eu/environment /life/project/ Projects/index.cfm?fuseaction=search.dspPage\&n_proj id $=1746 \&$ doc Type $=$ pdf 